Okeford Fitzpaine, Dorset. ${ }^{1}$ The proof which it was supposed to give of the absence of that zone at Richmond consequently falls to the ground.

In conclusion, I have to express my sincere thanks to Mr. G. C. Crick for his ever ready help to me in the identification of Cephalopods; to Mr. F. Chapman for identifying the foraminifera ; and to Dr. Hinde for kindly sending me the fossils collected at Battlebridge to examine.

\title{
INOTICES OF MFIMOIRS.
}

Notes on Rogkall Island and Bank. With an Account of the Petrology of Rockall, and of its Winds, Currents, etc. ; with Reports on the Ornithology, the Invertebrate Fauna of the Bank, and on its previous History. Transactions of the Royal Irish Academy, vol. xxxi (1897), pt. 3, pp. 39-98, with plates ix-xiv. 7 IHIS memoir contains the results of an exploration carried on under the direction of the Rev. W. Spotswood Green, of the Irish Fisheries Board, with the assistance of Mr. Harvie Brown, Mr. R. M. Barrington, and a committee of the Royal Irish Academy. In June, 1896, the s.s. "Granuaile," of the Congested Districts Board, made two visits to the Rockall Bank, but none of the party of naturalists on board of her were able to effect a landing upon Rockall itself, though some interesting sketches and photographs were made of it, and valuable collections obtained from the surrounding seas.

The Rockall Bank is situated in the Mid-Atlantic, and it is separated from the plateau on which the British Islands stand by seas having a depth of from 1,300 to 1,600 fathoms. The bank is 150 miles long from N.E. to S.W., by about 50 miles wide, within the 200-fathom line, and about half that extent within the 100-fathom line; it is resorted to by fishing-craft at certain seasons, but the amount of fishing carried on there has not been so great as was at one time anticipated.

Rockall itself, which is situated in lat. $57^{\circ} 36^{\prime} \mathrm{N}$., long. $13^{\circ} 42^{\prime} \mathrm{W}$., is said by Captain Basil Hall to be "the most isolated speck of rock in the world." It is 240 miles distant from the Irish coast, 290 miles away from the nearest point of Scotland, and 170 miles from St. Kilda. It is only about 250 feet in circumference at its base, and about 70 feet in height. At a radius of $2 \frac{1}{2}$ miles from the rock the depths are from 40 to 70 fathoms, but within this area two other small rocks rise nearly to the surface of the sea. "Haslewood Rock' is a small half-tide detached rock, bearing N.E. by N. $1 \frac{1}{2}$ cables from Rockall, and 'Helen's Reef' (so called from a vessel that was wrecked upon it) is $\mathbf{1} \frac{3}{4}$ miles E. by S. from Rockall, and has about six feet of water upon it at low-water.

It has sometimes been suggested that Kockall might form an invaluable position to be utilized for a ligluthouse or a meteorological

1 Geol. MaG., Dec. IV, Vol. III (1896), p. 200. 
station. But minute as it is in size, and exposed as it is to the full swell of the Atlantic, which rises and falls there more than 12 feet in the calmest weather, such use of the rock appears to be out of the question. Indeed, fisbermen and sailors from men-of-war have only occasionally effected a landing upon it, under the most favourable conditions, with the greatest difficulty. The rock lies out of any of the usual tracks followed by steamships and sailing vessels in crossing the Atlantic. At a distance it appears, with its dark-coloured base and top whitened with the dung of innumerable sea-fowl, so like a ship under full sail, that in war-time the captains of men-of-war are said to have been frequently deceived by it.

Although no landing was effected during the recent investigation of Rockall, the exploring party managed to secure a number of interesting drawings and photographs of the rock. The Rev. W. S. Green describes the general character of the mass in the following words :- "The east face seemed like a great slab of gray granitoid rock (and I was within 20 yards of it), with rectangular joints broken off at the north, so as to show the square edge of another slab, and this was in turn broken off, showing the face of a third." This granitoid mass "rests on a rock showing a kind of bedding or jointing (?), dipping about east, and at an angle of $30^{\circ}$ or so."

So far as is known, no specimens have ever been obtained from this underlying mass on the west or south-west of the rook, and it is impossible to say whether it consists of sedimentary materials, of stratified tuffs, or of some fissile igneous rock.

Of the overlying granitoid mass, however, the relations of which seem to strikingly resemble those of an intrusive sheet, the indefatigable exertions of Professor T. Rupert Jones have resulted in bringing together three specimens. These have been submitted to Professor Judd for examination in the Geological Laboratories of the Royal College of Science. One of these specimens was obtained by Basil Hall as long ago as the year 1810, when Rockall was visited by H.M.S. "Endymion"; the others were obtained by Commander Hoskyn and Captain Inskip respectively, during the visit of H.M.S. "Porcupine" to the rock in 1862 . In each case the specimens were obtained by an active sailor, with a line attached to him, springing from a boat on to the rock, and, when he had secured fragments of it, throwing himself into the sea to be towed back to the boat.

Two of the specimens were found on microscopic examination to be distinctly granitic in structure, the quartz, felspar, and augite of which they are made up being allotriomorphic. Their structure, however, resembles that of the granite-porphyries rather than that of the true granites. The third specimen, while made up of the same minerals, is distinctly hypocrystalline, having the kind of groundmass which Rosenbusch distinguishes as 'bypidomorphic.' This variety, having a darker colour, as well as a finer texture, may not improbably form veins, or possibly inclusions, in the main mass; or it may belong to the edge of the intrusive sheet. All the rocks are somewhat drusy or miarolitic in structure.

Detailed microscopical examination shows that the material of 
Rockall is really of a very unique and interesting character. The rock consists of three minerals-a soda-augite (ægirine and acmite), quartz, and albite. Accessory minerals, other than maguetite and apatite, appear to be very rare in it. The proportion of these ingredients is somewhat different in the several examples of the rock, the darker-coloured variety containing more of the soda-augites.

The order of erystallization of the minerals of the rock is easily determined. The soda-augite (ægirine and aomite) was the first to separate, the centres of the crystals being grass-green ægirine, and the peripheral portion brown acmite, each mineral exhibiting its characteristic pleochroism. After the augite, albite separated, and the quartz crystallized out last.

Apatite needles are found enclosed in all the minerals of the rock, and among the secondary minerals of the rock are magnetite, quartz, arfvedsonite, and a blue soda-amphibole.

The specific gravities of different specimens determined by Mr. H. S. Hinton, F.G.S., were found to vary from $2 \cdot 71$ to $2 \cdot 94$.

An analysis of the rock of the highest specific gravity and darkest colour, which was made by Mr. C. J. S. Makins, under the superintendence of Professor W. A. Tilden, gave the following result :-

$$
\begin{array}{lcccccc}
\text { Silica } \ldots & \ldots & \ldots & \ldots & \ldots & \ldots & 73 \cdot 60 \\
\text { Alumina } & \ldots & \ldots & \ldots & \ldots & \ldots & 4 \cdot 70 \\
\text { Ferric Oxide } & \ldots & \ldots & \ldots & \ldots & \ldots & 13 \cdot 10 \\
\text { Manganese } & \text { Oxide } & \ldots & \ldots & \ldots & \ldots & \cdot 93 \\
\text { Nickel Oxide } & \ldots & \ldots & \ldots & \ldots & \ldots & .06 \\
\text { Magnesia } & \ldots & \ldots & \ldots & \ldots & \ldots & \cdot 11 \\
\text { Lime } \ldots & \ldots & \ldots & \ldots & \ldots & \ldots & .37 \\
\text { Soda } \ldots & \ldots & \ldots & \ldots & \ldots & \ldots & 6.96 \\
\text { Potash } \ldots & \ldots & \ldots & \ldots & \ldots & \ldots & \text { minute trace } \\
\text { Phosphoric } & \text { Acid } & \ldots & \ldots & \ldots & \ldots & \text { traces } \\
& & & & & & 99 \cdot 83
\end{array}
$$

This analysis shows the mineralogical constitution of the rock to be as follows :-

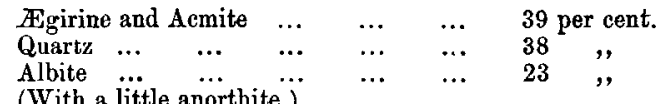

The soda-augite (ægirine and acmite) appear to have a very similar composition to that of the rocks of the Christiania district described by Brögger, while the bulk analysis of the rock resembles that of some of the quartz ceratophyres and some of the quartzpantellerites of Foerstuer.

The nearest analogues of the rock of Rockall are to be found among the grorudites of Brögger (quartz-tinguaite of Rosenbusch). Professor Brögger, who has examined a section of the rock sent to him, agrees that the rock is similar to his grorudites in mineral composition, but he demurs to it being included under his name on account of the differences in structure. On the other hand, the rock of Rockall is shown to differ from the Natron-granites, some of which it resembles in structure, by its high proportion of augite. 
Under these circumstances it is proposed to give to the material of Rockall a distinctive name and to call it 'Rockallite.'

Rockallite is defined as a rock having the structure of the 'granite-porphyries' but belonging to the extreme variety of the soda-bearing acid rocks. It is an ægirine-quartz-albite rock, intermediate in structure and composition between the soda-granites on the one hand and the grorudites on the other, and presenting points of analogy with some soda-ceratophyres. Among lavas or effusive rocks, rockallite is probably represented by some quartz-pantellerites.

With respect to the age and relations of the rock forming the singular isolated mass of Rockall, the materials for arriving at a judgment must be admitted to be very small. If the rock, on which the igneous mass lies and over which it appears to have been thrust, could be examined, and especially if this were shown to be a stratified rock with fossils, the evidence thus afforded would be of great value. At present, however, we have nothing but general analogies to guide us. The nearest resemblance to rockallite js found, as we have seen, among the Post-Silurian dykes in the Christiania district so admirably investigated by Professor Brögger; and it may be that in Rockall we have a similar intrusive mass of the same period that has escaped destruction by denudation. But it must be remembered that among the Tertiary rocks of the Western Isles of Scotland, in St. Kilda (which is the nearest land to Rockall), in Skye, Ardnamurchan, Mull, and Arran, we have granites and granite-porphyries containing soda-augites and soda-amphiboles. Some rocks, indeed, approaching in character to rockallite, occur among the Tertiary eruptives, and it is, therefore, by no means impossible that rockallite may belong to the same recent period.

In another division of the memoir before us, Professor Grenville A. J. Cole describes the rock-specimens dredged on the Rockall Bank. These all show a remarkable uniformity of character, as if the original source of the material had been true local rock-masses rather than any ice-drift.

The great mass of the specimens appears to be basalt of the ordinary type. Some of these appear to be destitute of olivine, and approximate to augite andesite or basalt andesite. $\operatorname{Some}$ are vesicular; others are more or less glassy in texture, and exhibit flow-structures. An andesitic pumice and a scoriaceous andesite, "well removed from the extreme basaltic types," were also found. With these igneous rocks was found one example of a fine-grained grey argillaceous and slightly micaceous sandstone, strikingly resembling the Ordovician sandstones in the altered strata of County Down.

Among specimens supplied by Mr. Cordeaux of Grimsby, and obtained by fishermen entangled in their lines when fishing on the Rockall Bank, are many basalts; also one specimen of an ordinary red granite with micro-pegmatite and a red sandstone, very similar to the Torridonian rocks.

Mr. R. H. Scott supplies to the memoir an account, illustrated by sketch charts, of the winds and currents in the district in which 
Rockall occurs. The sources of information for these charts are the logs of Her Majesty's ships since 1830 and of vessels in the Mercantile Marine since $18 \tilde{4} 4$.

Mr. H. N. Dickson, of the Chemical Laboratory, University Museum, Oxford, gives the results of a series of analyses by which the degree of salinity of a number of samples of sea-water collected off Rockall was determined.

The memoir concludes with a series of Reports on the Natural History of Rockall and the surrounding seas. That on the Ornithology is by Mr. J. A. Harvie Brown; that on the Mollusca by Mr. A. R. Nichols, of the Science and Art Museum, Dublin; that on the Crustacea by Mr. W. T. Calman, B.Sc., and Professor E. P. Wright; that on the Chætopoda by Professor M'Intosh; that on the Echinodermata by Mr. W. P. Sladen; that on the Polyzoa by Miss L. R. Thornelly; and that on the Sponges by Professor R. von Lendenfeld.

Professor T. Rupert Jones, who has been untiring in his efforts to obtain new light on this most interesting locality, contributes a very valuable sketch of the previous history of Rockall, and a general epitome of all that has hitherto been published concerning it.

The memoir is well illustrated by three coloured drawings of Rockall from sketches by the Rev. W. S. Green; six photographs of the rock taken from different directions; a beautiful plate, showing the characters of the two types of 'rockallite' as seen in thin slices under the microscope, drawn by the skilful hand of Mrs. Cole; and twelve charts showing the directions of currents around Rockall during every month of the year.

The Royal Irish Academy is to be congratulated upon their spirited attempt to gain new light upon this interesting locality, and no less so on the manner in which the results achieved have been presented to the public in their 'Transactious.'

\section{卫FVIFW}

I. - Mrmoirs of the Geological Survet of Fingland and Wales. "The Geology of the lole of Purbeck and WeyMouth." By Aubrey Strahan, M.A., F.G.S. 8vo: pp. xi and 278 ; 5 plates from photographs, 2 folding plates, and 183 other illustrations in the text; map and 3 plates of sections at the end of the book. (London, 1898. Price 10s. 6d.)

T $N$ his preface the Director-General of the Geological Survey remarks that "when the revision of the Geological survey maps of the Isle of Wight was completed in 1888, it was deemed advisable to continue the work into the adjacent parts of Dorset. The task of resurveying the classic Isle of Purbeck and the region round Weymouth was entrusted to Mr. A. Strahan, who had mapped the Secondary formations of the Isle of Wight. In two years the field-work was finished as far as the top of the Chalk, and the mapping of the Tertiary deposits was subsequently completed by Mr. U. Reid." 